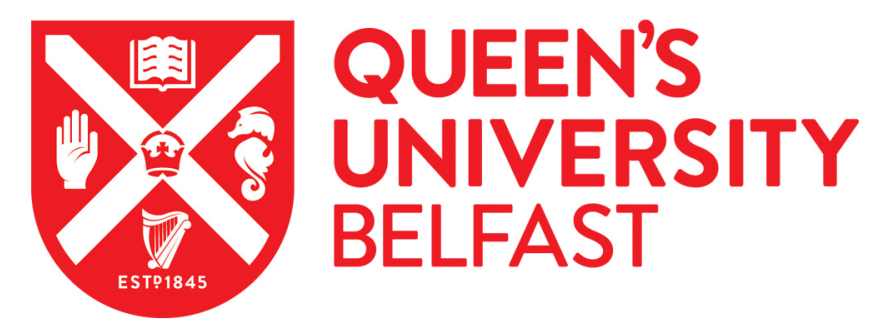

\title{
Methods and approaches to advance soil macroecology
}

White, H. J., León-Sánchez, L., Burton, V. J., Cameron, E. K., Caruso, T., Cunha, L., Dirilgen, T., Jurburg, S. D., Kelly, R., Kumaresan, D., Ochoa-Hueso, R., Ordonez, A., Phillips, H. R. P., Prieto, I., Schmidt, O., \& Caplat, P. (2020). Methods and approaches to advance soil macroecology. Global Ecology \& Biogeography. https://doi.org/10.1111/geb.13156

Published in:

Global Ecology \& Biogeography

Document Version:

Peer reviewed version

Queen's University Belfast - Research Portal:

Link to publication record in Queen's University Belfast Research Portal

Publisher rights

Copyright 2020 Wiley. This work is made available online in accordance with the publisher's policies. Please refer to any applicable terms of use of the publisher.

\section{General rights}

Copyright for the publications made accessible via the Queen's University Belfast Research Portal is retained by the author(s) and / or other copyright owners and it is a condition of accessing these publications that users recognise and abide by the legal requirements associated with these rights.

Take down policy

The Research Portal is Queen's institutional repository that provides access to Queen's research output. Every effort has been made to ensure that content in the Research Portal does not infringe any person's rights, or applicable UK laws. If you discover content in the Research Portal that you believe breaches copyright or violates any law, please contact openaccess@qub.ac.uk. 


\section{Methods and approaches to advance}

\section{2 soil macroecology}

\section{Abstract}

4 Motivation and aim: Soil biodiversity is central to ecosystem function and services. It represents

5 most of terrestrial biodiversity and at least a quarter of all biodiversity on Earth. Yet research into

6 broad, generalisable spatial and temporal patterns of soil biota has been limited compared to

7 aboveground systems due to complexities of the soil system. We review the literature and identify key

8 considerations necessary to expand soil macroecology beyond the recent surge of global maps of soil

9 taxa, so that we can gain greater insight into the mechanisms and processes shaping soil biodiversity.

10 We focus primarily on three groups of soil taxa (earthworms, mycorrhizal fungi and soil bacteria) that

11 represent a range of body sizes and ecologies, and, therefore, interact with their environment at

12 different spatial scales.

13 Results: The complexities of soil, including fine-scale heterogeneity, 3D habitat structure, difficulties with taxonomic delimitation, and the wide-ranging ecologies of its inhabitants, require the classical macroecological toolbox to be expanded to consider novel sampling, molecular identification, functional approaches, environmental variables, and modelling techniques.

Main conclusion: Soil provides a complex system within which to apply macroecological research, yet it is this property which itself makes soil macroecology a field ripe for innovative methodologies and approaches. To achieve this, soil-specific data, spatiotemporal, biotic, and abiotic considerations are necessary at all stages of research, from sampling design to statistical analyses. Insights into whole ecosystems and new approaches to link genes, functions and diversity across spatial and temporal scales, alongside methodologies already applied in aboveground macroecology, invasion ecology and 
aquatic ecology, will facilitate the investigation of macroecological processes in soil biota, which is

24 key to understanding the link between biodiversity and ecosystem functioning in terrestrial ecosystems.

\section{Introduction}

Macroecology strives to understand the generality of emergent patterns of aggregate ecological entities (McGill, 2019). The area has moved beyond large scale biodiversity maps for many aboveground taxa, addressing process-based patterns including, latitudinal gradients of diversity (Stehli, Douglas \& Newell, 1969), species-area relationships (Rosenzweig, 1995), species-energy relationships (Gaston, 2000) and broad-scale responses of diversity to anthropogenic pressures (Newbold et al., 2015), across spatial and temporal scales. There are, however, still significant knowledge gaps surrounding many questions of macroecology and biogeography, and new techniques to investigate these, in soil ecology (Eisenhauer et al., 2017).

Soil biodiversity regulates nutrient cycling and makes other central contributions to net primary production and carbon sequestration (Bardgett \& Wardle, 2010; Wagg, Bender, Widmer \& van der Heijden, 2014) across spatial scales (Delgado-Baquerizo et al. 2020). Given the importance of soil biodiversity, knowledge of spatial and temporal distributions of soil organisms is essential for both management of terrestrial ecosystems and predicting future ecosystem functioning under global environmental change (Wagg et al., 2014; Crowther et al., 2019). Recently, there has been an increased interest in describing the generality of emergent patterns of soil biodiversity (e.g. Shoemaker, Locey \& Lennon,, 2017; Shade et al., 2018; Thakur et al., 2019), although, difficulties in observing many soil organisms directly has limited this. Further, it has been challenging to formulate a common macroecological framework across soil taxa given the sheer range in body sizes and ecologies, from bacteria to macrofauna, which vary in the scale at which they perceive the environment. Methodological and taxonomic challenges have hindered macroecological research into belowground systems concerning species richness, spatial distributions, ecosystem functioning and 
spatial scaling (Schröder, 2008; Decaëns, 2010; Shade et al., 2018). The challenges of soil macroecology, therefore, arise not only across spatial and temporal scales, but across the organisational hierarchy of species, communities, and ecosystems.

At a species level, species distribution models (SDMs) are frequently employed to relate the spatial distribution of aboveground species to their environment (Elith \& Leathwick, 2009), yet there are very few examples of SDMs applied to soil-dwelling species other than earthworms (e.g. Palm, van Schaik \& Schröder, 2013; Marchán et al., 2015). For many soil taxa, this is a result of not having sufficient species-level occurrence data from various geographic locations spanning environmental gradients at relevant spatial scales (Schröder, 2008). For other taxa (i.e. collembola, but see Caruso et al., 2009) these data are already available, which begs the question of why the modelling of belowground species distributions has been so limited. There is, therefore, a huge opportunity to expand soil macroecological research through species distributions modelling, as long as we are able to overcome the challenges of the soil system itself.

Community biodiversity patterns include well-established macroecological relationships, such as the species-area relationship and latitudinal gradients (e.g. Rosenzweig, 1995), distance-decay curves (Nekola and White, 1999), as well as models linking biodiversity patterns to environmental variables such as the species-energy relationship (e.g. Evans et al. 2008). These relationships have formed the basis of macroecological theory and our knowledge of how diversity is arranged in space and time, at a range of spatial, temporal, and hierarchical scales. Although community assembly in soil organisms has been investigated (Caruso et al., 2012; Dirilgen et al. 2018), generalisable spatial and temporal patterns of soil biodiversity have yet to be determined to the degree that they have above ground (but see Caruso et al., 2019). For microbes in particular, studies have tended to focus on individual taxa and metabolic genes, yet it is the emergent properties of communities which influence ecosystem functioning and services (Ladau and Eloe-Fadroush, 2019), and, therefore, need to be considered if we are to expand the field of soil macroecology. 
At the ecosystem level, there have been huge advancements in our ability to model whole ecosystem functioning, particularly within the context of global change (Allan et al., 2015; De Laender et al., 2016). The development of measures of functional diversity (the range and variation of ecological traits present within an area) has facilitated this. Aboveground, these measures have been used to investigate key conservation issues such as biotic homogenisation (White et al., 2018a). Given the importance of soil and soil biodiversity in ecosystem functioning and global cycles (DelgadoBaquerizo et al., 2020), functional traits have much to offer soil macroecology. The measurement of functional traits is becoming increasingly feasible from a technical perspective (e.g. proteomics and isotope tracer-enabled analysis of proteins and metabolites, trait database availability), and they can be directly linked to ecosystem level processes (Hooper et al., 2005). There is a need, therefore, to continue to develop methods to measure functional diversity and broad scale functioning of soil organisms, and understand, for example, how these respond to environmental gradients. Applied properly to soil organisms, macroecological approaches will provide us with another tool to tackle global challenges related to soil functioning and soil protection.

\section{Aims and scope of this review}

To move beyond mapping of soil taxa in space and identify broad, generalisable spatial and temporal patterns of soil biodiversity and their underlying mechanisms, we need to consider: the biodiversity data; the spatio-temporal context of the system and mechanisms under investigation; the biotic components shaping these patterns; and the abiotic components shaping these patterns. We discuss each of these sets of considerations and review current methods and future directions for each. Our intention is not to provide a systematic review of macroecological patterns of multiple soil taxa, but instead, to focus on the specific characteristics of the soil system that have limited soil macroecology, and review and propose methods that would help address these limitations. To accomplish this, we use earthworms, mycorrhizal fungi and soil bacteria as focal taxa. These groups have all had their global biodiversity modelled (earthworms, Phillips et al., 2019; fungi, Kivlin et al., 2011; Tedersoo et al., 2014; Pärtel et al., 2017; soil bacteria, Delgado-Baquerizo et al., 2018), and they reflect the 
diversity of taxa which inhabit soil through their variation in body size, life forms and ecology which leads to differences in the spatial scale at which they perceive and interact with their environment. They, therefore, provide a range of robust examples of the issues that have hindered soil macroecological research to date, and the diversity in approaches required to overcome these difficulties.

\section{Data considerations}

\section{Data availability}

Initiatives exist to establish standardised sampling protocols to collect new data on soil biodiversity (Philippot, Ritz, Pandard, Hallin \& Martin-Laurent, 2012), e.g. the Earth Microbiome Project (Thompson et al., 2017) and EcoFINDERS (Lemanceau, 2011), as well as bring together existing soil biodiversity data (see Table 1) into accessible databases and frameworks, e.g. the Global Soil Biodiversity Initiative (www.globalsoilbiodiversity.org) and Ramirez et al. (2015). Pärtel et al. (2017) use a standardised dataset of metabarcode information (MaarjAM database, Öpik et al., 2010) to model spatial variation in species pool, local and dark diversity (members of the species pool which are absent locally) alongside their respective environmental correlates. These standardised data provide a suitable means for investigating large scale biodiversity patterns (e.g. species-area relationships, latitudinal gradients etc.), and, in fact, better satisfy the criteria of comparability across sites and studies than many datasets of macro-organism distributions which show large variation in sampling methodology and effort.

The Global Soil Biodiversity Initiative and Ramirez et al. (2015), on the other hand, aim to maximise the potential of existing data by establishing global platforms that combine databases of all types of soil biodiversity data, including molecular, taxonomic, and morphological measurements and traits. Assembling data from multiple sources is complicated due to variability in taxonomic resolutions, unresolved taxonomies (Cameron, Decaëns, Lapied, Porco \& Eisenhauer, 2016) and lack of 
standardisation of sampling techniques that cause technical factors (e.g. sampling protocol, primer and sequencing platform) to be an important source of inter-study variability (Ramirez et al., 2018). Some studies choose to only include data collected using specific methodologies to reduce inter-study variability (e.g. European earthworm diversity maps, Rutgers et al., 2016; 2019), yet, nonstandardised datasets can still provide important global insights into the ecological preferences and geographical ranges of species (Ramirez et al., 2015). These data will complement standardised sampling protocols when analysed appropriately, for example using meta-analytical or machine learning approaches (Hendershot, Read, Henning, Sanders \& Classen, 2017; Ramirez et al. 2018). Substantial geographic gaps in sampling, however, need to be addressed (Cameron et al., 2018) if we are to determine generalisable patterns of biodiversity, and model predictions should be refined and updated as empirical datasets become increasingly available.

\section{Measuring and defining soil biodiversity}

To study many macroecological patterns such as species-abundance distributions, species-area relationships and latitudinal gradients, we first need to identify the species. However, challenges remain with identification of many soil taxa (Soininen, 2012); the huge diversity of soil organisms combined with their small size (Schaefer et al., 2010), has led to a distinct lack of taxonomic knowledge of soil biodiversity (Decaëns, Lavelle \& Jiménez, 2008; Phillips et al., 2017).

Biogeographic realms at multiple spatial scales, therefore, exist, where every new place sampled, especially remote locations, can give huge volumes of undescribed species or sequences that cannot be matched to any known species or genus-level taxon (Decaëns, 2010; Fierer, 2017). Indeed, even urban systems such as Central Park in New York City, can harbour large volumes of undescribed soil biodiversity (Ramirez et al. 2014), and earthworms, a comparatively well-studied group with relatively low diversity, have had a large number of cryptic species revealed through DNA barcoding (King, Tibble \& Symondson, 2008).

Gene-based diversity assessments of environmental DNA (eDNA) are a promising toolset for facilitating large scale sampling of soil diversity (Bik et al., 2012; Deiner et al., 2017). Species can be 
identified using short metabarcodes and small samples of soil (e.g. earthworms, Bienert et al., 2012). eDNA has already furthered macroecological research, for example, through the detection of earthworm diversity at the landscape-scale, revealing impacts of abiotic factors not detected using traditional survey methods (Pansu et al., 2015). Nevertheless, the degree to which eDNA-based diversity estimates capture the living soil biota (rather 'relic' DNA) is unclear (Lennon et al., 2018; Ruppert, Kline and Rahman, 2019). Furthermore, this technique can vary with soil organic matter content and type, complicating the comparison of biodiversity patterns across environments and highlighting the continued, pressing need for the standardization of methodologies (Philippot et al., 2012; Geisen et al., 2019).

In particular, many molecular studies use targeted sequencing of specific marker genes or gene regions, which serve as 'barcodes'. Sequence differences within the "variable regions" of the marker genes are used to identify operational taxonomic units (OTUs), which may serve to delineate taxa below the genus level (e.g. earthworms, Pansu et al., 2015; fungi, Pellissier et al., 2014; Tedersoo et al., 2014). However, there is no universal threshold for an eukaryotic OTU, and this may well be clade-specific, and dependent on the barcode length and region of choice (Mysara et al., 2017). Despite recent technological advances in sequencing and bioinformatic pipelines to process high-throughput amplicon sequences, considerable challenges remain when using gene-based methodologies (Nesme et al., 2016). Errors or biases can arise from different DNA extraction methods (İnceoğlu, Hoogwout, Hill \& van Elsas, 2010), primer specificity, sequencing chemistries (i.e. short read length, Tedersoo et al., 2015; Tremblay et al., 2015), and bioinformatic processing, as well as difficulties with OTU delimitation and chimeras (Orgiazzi, Dunbar, Panagos, de Groot \& Lemanceau, 2015), and lack of matching current database entries (e.g. fungi; Tedersoo et al., 2014, bacteria; Ramirez et al., 2014; Thompson et al., 2017). These can confound diversity estimates in cross-study comparisons (Fierer, 2017; Thompson et al., 2017). Recent developments in clustering algorithms, i.e. a reference-free approach to resolve sequence variants at a single nucleotide resolution (Callahan, McMurdie \& Holmes, 2017; e.g. Deblur, Amir et al., 2017), could offer stable identifiers across different studies (Thompson et al., 2017), facilitating data reusability and integration of multiple data 
sets (Amir et al., 2017), thus maximising the potential of gene-based surveys in soil macroecology (Geisen et al., 2019). Alternatively, DNA-targeted enrichment (bait capture) allows more efficient recovery of sequence information, not relying on sequence affinity as strongly as PCR (Dowle et al. 2016). DNA enrichment can be applied to a range of different sample sources, in individual or pooled samples and can be used for recovering exogenous DNA present in environmental samples (Shokralla et al. 2016).

Many studies now focus on alternative dimensions of biodiversity to taxonomic diversity. Functional diversity, which measures the diversity and range of traits within a community, can be closely linked to ecosystem functioning (Heemsbergen et al., 2004; Hooper et al., 2005). Shifting from taxonomic to functional information can provide a way to unify the study of soil macroecology: the units are no longer species, or taxa, but functions and the diversity of functions expressed, which are relevant across taxonomic groups. Macroecological patterns that emerge from traits include trait-area and time relationships (e.g. White et al., 2018b), and functional diversity gradients (e.g. Meynard et al., 2011), which further our knowledge on the spatial, temporal and environmental structuring of ecological traits and ecosystem functioning (Violle et al., 2014), and provide new insights into community assembly theory (Smith et al., 2013). Due to the key ecosystem functions that soil biodiversity provides (Heemsbergen et al., 2004), we advocate a concerted shift towards functional approaches within soil macroecology through the following methodological and data options.

Trait databases facilitate the investigation of trait composition of soil communities. Morphological, physiological and phenological traits are present in the literature for many soil invertebrates due to their relative ease of measurement (e.g. carabid beetles, Barbaro \& van Halder, 2009: earthworms, Hedde et al., 2012; collembola, Martins da Silva et al., 2016; Bonfanti et al., 2018: ants, Bishop et al., 2016). For soil bacteria and fungi, on the other hand, characterisation of morphological, physiological and phenological traits can be more challenging since isolation of individual species for trait measurements is not feasible in most cases (Krause et al., 2014, Zanne et al., in press). Two recently published, large global databases, FungalRoot (Soudzilovskaia et al. 2020) and the Fungal Functional Database (FUNfun, Zanne et al. 2020) however, will facilitate better understanding of trait 
composition of fungal communities, their interactions with plants, and their effects on worldwide on ecosystem functioning (Powell \& Rillig 2018). However, as with many taxa, fungal trait databases are often incomplete (Zanne et al. 2020). There has also been a concerted effort to quantify microbial functions in soil due to their importance for key ecosystem functions (Aguilar-Trigueros et al. 2015; Zanne et al. 2020) through standardized 'omics' and enzymatic approaches (Dawson et al., 2019), as well as the measure of climate tolerances to investigate life history trait trade offs at large spatial scales (Maynard et al., 2019).

'Omic'-based functional analyses (e.g. proteomics, metabolomics) have been used to determine broad-scale patterns in fungi (Tedersoo et al., 2014) and bacteria (Fierer \& Jackson, 2006; DelgadoBaquerizo et al., 2018). These methods enable the categorisation of soil microbes by their ecological strategies (e.g. Fierer, 2017), therefore bypassing the taxonomic deficit problem and focusing on functional diversity. Functional 'omics' approaches can be used in experimental community ecology studies to provide information on potential ecosystem functioning (Maron, Ranjard, Mougel \& Lemanceau, 2007), such as the diversity of protein-coding gene categories e.g. antibiotic resistance genes and osmoregulatory genes (Fierer et al., 2012; Bahram et al., 2018), and soil enzyme substrate specificity (Caldwell, 2005) in nutrient cycling, as well as community structure and dynamics within the soil (Arsène-Ploetze, Bertin \& Carapito, 2015). Unlike gene-based approaches, protein-based 'omic' approaches (metaproteomics) capture the active component of soil biomass (Blagodatskaya \& Kuzyakov, 2013), and thus avoid overestimating diversity from dormant or dead biomass (Carini et al., 2016; but see Papp et al., 2018).

Despite limitations (i.e., transcriptomics may reveal potential, rather than fulfilled functions, Prosser, 2015), elucidating the underlying molecular mechanisms supporting functions could help to unlock the functional networks that interact to sustain soil properties (e.g. Bonfante and Genre, 2010). Semicontrolled experiments can build novel bridges with complex natural systems. For example, we recommend mesocosm experiments coupled with "omics" approaches designed to identify longitudinal biological responses of soil biota to microbiomes (e.g. soil and rhizosphere) and plants, although destructive sampling is a limitation. Further still, defining a global transcriptome-based 
delineation of functional entities, and obtaining a landscape of their similarities and differences based on differential expression of genes across different combinations of hierarchical levels and abiotic factors, for example, could help to derive the sets of genes involved in specific ecological processes that could be targeted in the field using metagenomics as a ground-truthing approach. Integrating multiple "omic" approaches, therefore, into community studies will lead to a rapid transformation in our empirical understanding of soil functioning and interactions (Swenson and Jones, 2017), and complementary approaches to DNA sequencing remain a priority for soil biodiversity research (Eisenhauer et al., 2017) as they will reveal new information on the mechanisms underlying ecosystem processes.

\section{Spatio-temporal considerations}

\section{Scale and structure}

Intra- and interspecific aggregations (Ettema \& Wardle, 2002), which result from the microscale heterogeneity of the soil system and limited dispersal of organisms, structure soil communities across spatial scales (Noguez et al. 2005; Decaëns, 2010; Bach et al., 2018; Thakur et al., 2019). In a Brazilian agricultural system, for example, geographical distance explained nearly 18 -times more variance in soil fungal community composition than environmental factors such as soil and climate characteristics (Gumiere, Durrer, Bohannan \& Andreote, 2016). Biogeography of soil bacteria has been investigated at a range of scales from continental and global scales (e.g. Fierer \& Jackson, 2006; Barberán et al., 2012; Bahram et al., 2018) to the landscape scale (Bru et al., 2011; Pasternak et al., 2013), and even at the centimeter scale (O'Brien et al., 2016). By taking multiple soil cores separated by only a few centimetres at sampling plots spaced $6 \mathrm{~m}$ apart, O'Brien et al. (2016) showed that there was extreme patchiness in community structure at the centimetre scale, but more general patterns in diversity, linked to fertilisation, were observed at the plot-level. This scale-dependent heterogeneity arises from the operating scale of mechanisms underlying community assembly. This needs to be 
accounted for in sampling design for investigations of spatial patterns of soil diversity with multiscale sampling protocols (e.g. Rasmussen et al., 2018). Additionally, macroecological analyses of soil diversity need to use techniques that model space, such as autoregressive models (Beale, Lennon, Yearsley, Brewer \& Elston, 2010), to address the strong spatial structuring in soil ecosystems, as demonstrated by spatial analyses of earthworm abundance, biomass and diversity (Joschko et al. 2006), and ectomycorrhizal fungi (Pickles, 2010). Similarly, techniques such as Principal Coordinates of Neighbourhood Matrices (PCNM) are useful in differentiating between spatial and environmental structuring of communities at different spatial scales (e.g. Columbian earthworm communities, Jiménez, Decaëns, Lavelle and Rossi, 2014).

The scale at which similar processes act varies between taxonomic groups due to variation in body size and life history, and is an important consideration when studying spatial patterns of soil communities (Montagna et al., 2018). When studying landscape scale processes, Jackson and Fahrig (2012) highlight the concept of the 'scale of effect' (the scale at which an ecological response is best predicted by the habitat structure) and recommend sampling areas far enough apart to ensure sample points are independent (i.e. taxa in one sample point do not directly interact with those in others). Thakur et al. (2019) present a conceptual framework splitting soil into spatial compartments at which different nested groups of soil organisms can be studied to test biodiversity theories: soil, where all size groups of organisms can be sampled; hotspots (rhizosphere and drilosphere), where meso- and micro-fauna can be sampled; and microsites (root tips and aggregates), where micro-fauna can be sampled. This compartmentalisation allows integration of body size into the investigation of classical ecological theory. Beyond simply considering 'scales of effect' and spatial compartmentalisation, we suggest researchers further draw upon work on investigating scaling issues in complex landscapes to build on the conceptual framework of Thakur et al. (2019) and inform sampling designs. For example, the problem of "coarse-graining" occurs when fine-scale information is aggregated to larger scales to reduce model complexity (Newman et al. 2019). By tracking how this leads to loss of information explicitly and investigating scaling relationships, corrections for statistical biases may be possible (Wu, 2004; Newman et al. 2019). 
The species-area relationship is a classical macroecological relationship which is well-established in aboveground biota. Judas (1988) applied the species-area relationship to published data on European lumbricid earthworm diversity, revealing a lower scaling exponent than those established in aboveground systems. One approach to investigate species-area relationships for ectomycorrhizal fungi is to use tree 'islands' of host plants, which, due to their obligate symbiosis, create an island species-area relationship (Peay et al., 2007). This approach, however, may not be transferable to other microbial organisms. Taxa-area relationships have also been applied to soil bacteria and fungi using samples taken from the corners of four nested quadrats (Sayer et al., 2013). This method, however, is likely to underestimate diversity at each quadrat size as it is only partially sampled and is more representative of a taxa-areal extent relationship. It does, however, still provide a useful study design to investigate key macroecological patterns of spatial scaling and turnover of community composition of multiple soil taxonomic groups.

As well as accumulation in space, temporal accumulation of species is an important part of macroecology, and community turnover and can be investigated using the species-time relationship. In aboveground literature, the species-time relationship has been studied far less frequently than the species-area relationship (White et al., 2006), and belowground, this lack of studies is even more pronounced (Ladau and Eloe-Fadrosh, 2019). The temporal component of soil biodiversity, however, is critical to consider. As well as hot spots of diversity, Kuzyakov and Blagodatskaya (2015) highlight 'hot moments' of soil microbial diversity which can occur either occasionally or regularly as a component of periodic processes within a system, often dependent on the temporally dynamic input of C into soil. Additionally, species interactions operate at multiple temporal scales and vary within and between taxa. For example, the connectivity of soil networks on abandoned arable land varies temporally during restoration (Morriën et al. 2017). Hence, for temporal questions, sampling is required at temporal scales relevant for the organisms of interest and the ecosystem properties with which they interact (Ettema \& Wardle, 2002; Bardgett et al., 2005; De Deyn \& Van der Putten, 2005). However, the appropriate scale remains an outstanding question in temporal biodiversity change of most soil organism groups (Eisenhauer et al., 2017; Shade et al., 2018). We, therefore, recommend 
sampling at multiple time scales depending on the question at hand to determine the temporal scales at which soil biodiversity varies, from macroevolutionary investigations (e.g. Schaefer and Caruso, 2019) to short-term dynamics (Kuzyakov and Blagodatskaya, 2015).

\section{Dimensionality}

To date macroecological patterns have been primarily conceptualised in a 2D context (e.g. speciesarea relationships, distance-decay relationships in geographic space, latitudinal gradients). However, where depth and/or height have a strong influence on the biodiversity estimates and community dissimilarity (e.g. marine systems, tropical forests and soils), there is much to be gained by explicitly extending these macroecological concepts to a third dimension. Given that soil community composition varies strongly with soil depth (e.g. fungi and bacteria, Fierer et al., 2003; Eilers et al., 2012; ants, Wong and Guénard, 2017; microfauna, Pausch et al., 2018), and key ecosystem processes are reliant on sub-soil fauna at different depths (Rumpel \& Kogel-Knabner, 2011; Ward, 2016), the integration of depth as a third dimension into macroecological theory is a key area to which soil ecologists can contribute. Expanding soil macroecology into this third dimension will be particularly important for obtaining comparable estimates of true soil diversity, for example through extension of species accumulation curves to depth profiles. Furthermore, it will enhance our understanding of species-environment relationships, and provide insights into interaction dynamics in 3D space. In order to do so, state-of-the-art sampling designs and modelling approaches will be required.

To address these questions it is essential that both soil biota and abiotic properties be sampled across depth profiles. For macrofauna, sampling must involve multiple methods (e.g. pitfall trapping, direct sampling, Berlese extraction, subterranean baiting) as each is known to capture different species (Fig. 1). For example, in a review of sampling methods Wong and Guénard (2017) identified seven studies in which more than $10 \%$ (range 12.3 to $44.4 \%$ ) of all ant species recorded were unique to subterranean samples; and would have been missed with conventional sampling methods. For smaller macro-organisms, such as collembolans and arthropods, core samples provide samples from across the depth profile, but these must be carefully sorted to maintain information on sample depths as 
combining multiple soil depths into a single sample can homogenize microscale variation

(Grundmann et al., 2001). For microbial organisms, microsampling of smaller soil quantities across the depth profile is advised (e.g. Dechesne et al., 2003), or 2D images of soil thin sections at multiple depths can be used to count bacterial cell distributions and construct 3D distributions (Raynaud and Nunan, 2014). Sampling of root-associated species such as mycorrhizal fungi, may be facilitated by incorporating information on the depth distribution of roots (e.g. Sosa-Hernandez et al., 2018). Depth distributions of many taxa can vary seasonally, for example, some earthworm species aestivate in lower soil layers during the summer (Gerard, 1967). Therefore, where feasible, sampling should be conducted seasonally to capture the full breadth of species depth distributions (e.g. Martay \& PearceHiggins, 2018).

A final opportunity for macro-ecological approaches related to dimensionality arises from the existence of soil communities ex situ, i.e. in soil micro-habitats above the soil proper. For example, true soil-dwelling invertebrates including springtails and mites occur in suspended soil at various heights (up to $35 \mathrm{~m}$ ) in canopies of subtropical and temperate rainforests (Rodgers and Kitching, 1998; Lindo and Winchester, 2006). In Canadian Western redcedar trees, 18 of the 53 springtail (Collembola) species recorded from suspended soils did not occur in the forest floor (Lindo and Winchester, 2006). In Indonesian oil palm plantations, suspended soil in frond axils of palm oil trunks supported much higher densities and biomasses of soil microfauna and mesofauna than belowground soil, with suspended soils contributing an estimated $28 \%$ of the overall soil fauna metabolism in plantations (Potapov et al., 2020). These contributions of suspended soils to overall diversity and community turnover, suggest that there is much to be gained by extending soil sampling aboveground in forest ecosystems (Fig. 1).

Information from vertical sampling may be integrated into the investigation of important macroecological patterns through the explicit incorporation of depth/height as a parameter standard macroecological approaches e.g. Does community similarity decay more rapidly with depth than horizontal distance?. However, more complex models will be required to investigate speciesenvironment relationships in 3D domains. For such applications, it may useful to turn to the marine 
literature where development of SDM techniques for 3D systems is already underway (e.g. Duffy \& Chown, 2017; Pérez-Costas 2019). Similarly, investigations into the scaling of interaction strengths within species networks can differ between two- and three-dimensional systems in terrestrial and marine realms, where advanced non-linear statistical approaches, 3D statistical point pattern models, and 3D agent based modelling have been successfully applied (see Raynaud and Nunan 2014;

369 Biotic considerations

\section{Dispersal}

The dispersal capacity of many soil biota, and thus the environment in which soil communities develop and interact, is often at a much finer resolution than the scale at which environmental variables are commonly measured (Grundmann \& Debouzie, 2000; Hendershot et al., 2017), and varies tremendously between and within different soil taxa (e.g. microbes, dispersing as spores, can generally disperse at larger scales than most soil animals). However, dispersal syndromes vary at multiple phylogenetic scales (e.g., fungi vs. bacteria and phylotypes within bacteria in Archer et al. 2019). Therefore, sudden environmental changes that favour specific dispersal modes, may then favour certain taxa and so drive community structure through an intensified propagule pressure of those taxa, thus dictating macroecological patterns. This process, as well as others, may operate at multiple scales. For example, some biogeographical 'rules' that apply to the distribution of vertebrates at the continental scale, e.g. range size-frequency distributions, can be detected in prokaryotes within an $8 \mathrm{~m} \times 8 \mathrm{~m}$ quadrat (Noguez et al. 2005), conflicting with the traditional idea that soil microbes are not limited by dispersal (Finlay, 2002). Overall, it is now well established that dispersal limitation is central to explain the distribution of all soil organisms, and that dispersal may differ at different phylogenetic levels (Davison et al., 2015; Archer et al., 2019). It is, therefore, crucial to include dispersal capacity into models of belowground species and to to take into account the fact that 
dispersal capacity varies greatly with size, ecology and life stage of the organism (Ettema \& Wardle, 2002; Soininen, McDonald \& Hillebrand, 2007).

Dispersal kernels are a frequently used tool in invasion ecology that can be used to incorporate dispersal into species distribution models (Meentemeyer, Anacker, Mark \& Rizzo, 2008). These describe the probability distribution of the distance travelled by an individual from a parent source and can be used to estimate the probability of colonisation (Franklin, 2010). Novel tools for implementing cellular automata models into SDMs which map accessibility from source cells are another promising recent development (Nobis \& Normand, 2014). Although implementing such models can be challenging as the dispersal characteristics of many soil organisms remain largely unknown (Schröder, 2008), molecular techniques provide tools to measure whole community dispersal of microbial systems (Peay, Garbelotto \& Bruns, 2010; Peay, Schubert, Nguyen \& Bruns, 2012). For example, within a biogeographical framework of plant host 'islands', Peay et al. (2012) use next-generation sequencing of propagules to demonstrate a dispersal limitation of one kilometre across a whole ectomycorrhizal fungal community. For earthworms on the other hand, visual tagging methods (Butt and Lowe, 2007) and X-ray scanning have been used to measure dispersal in addition to molecular methods (Mathieu, Caro \& Dupont, 2018). Using these newer technologies to determine active and passive dispersal of soil organisms will allow movement-based theories of ecology to be tested (Thakur et al., 2019) that contribute to spatial and temporal biodiversity patterns across scales (Gumiere et al., 2016; Dirilgen et al., 2018).

\section{Interactions}

Microbiota, including soil fungi and bacteria, are almost always sampled at scales larger than that at which individuals interact, therefore lumping together sets of taxa that partition different resources, or occupy different microhabitats (Fierer \& Lennon, 2011; Bach, Williams, Hargreaves, Yang \& Hofmockel, 2018). This can greatly influence observed macroecological patterns, such as the speciesabundance distribution (Shoemaker et al., 2017). Multiscale sampling is recommended to provide novel insights into the processes and mechanisms underlying spatial organisation of communities of 
soil taxa of various body sizes. Using soil aggregate isolation techniques when sampling, for example,

414 will help characterise biodiversity of soil microbes relevant to the spatial scale at which individuals

415 interact and use resources (Bach et al., 2018).

416 Network analyses based on Spearman's rank correlations have been used to determine co-occurrences

417 of soil bacteria (Barberán, Bates, Casamayor \& Fierer, 2012), but due to the complex three-

418 dimensional structure of soil, these networks may not always be indicative of real species interactions

419 (Morriën, 2016). The simulation approach used by Raynaud and Nunan (2014), for example, shows

420 that interspecific interactions between bacterial species are substantially lower than what you may

421 expect given the bacterial diversity frequently measured in soil samples (see Dimensionality section

422 above). For earthworms, stable isotopes have been used to determine interactions between invasive species of earthworms within a $2 \mathrm{~km}^{2}$ area in the USA (Zhang et al., 2010), providing a sophisticated tool to address the challenge of non-transparency of the soil medium in identifying biotic interactions where they cannot easily be observed.

There is a momentum to improve aboveground models of species distributions by incorporating biotic interactions (e.g. Staniczenko, Sivasubramaniam, Suttle \& Pearson, 2017). While challenging, this research track is promising for soil macroecology. Indeed, the particular importance of addressing this challenge for soils is highlighted by the substantial contribution of biotic interactions in shaping soil organisms' distributions (Raymond, Wharton \& Marshall, 2013; Bahram et al., 2018), and the complex aboveground-belowground interactions that have been observed globally (De Deyn \& Van der Putten, 2005). Joint SDMs account for species interactions via correlation matrices of cooccurrence (Pollock et al., 2014) and can disentangle species interactions from environmental correlates in large multispecies datasets (Warton et al., 2015), holding promise for soil macroecological studies.

436 Aboveground and belowground systems are linked by food web interactions and nutrient fluxes 437 through plant litter decomposition (Wardle et al., 2004; de Vries et al., 2013), modulation of soil physical properties by plant diversity (Gould, Quinton, Weigelt, De Deyn \& Bardgett, 2016), and 
direct species-species interactions (Bardgett \& Wardle, 2010). Soil biodiversity data, therefore, can be

440 extremely powerful when used in conjunction with aboveground community data (Ramirez et al.,

441 2015). This is particularly true for mycorrhizal fungi, which form mutualisms with plants, and for

442 which host specificity is an important geographical constraint on species distributions (Sato et al.,

443 2012). Hence, studies of community structure and biogeographic patterns of soil fungi are

444 significantly improved when data on plant diversity and distributions are included within their models

445 (Pellissier et al., 2014; Vályi et al., 2016; Koyama, Maherali and Antunes, 2019). To this end, the

446 FungalRoot database (Soudzilovskaia et al., 2020) provides key data on mycorrhizal associations with

447 which to study the macroecology and biogeography of these interactions.

448 Feedbacks between the aboveground and belowground systems, however, are difficult to predict at

449 large scales, as species interactions are complex (Wardle et al., 2004; De Deyn \& Van der Putten,

450 2005), vary along latitudinal gradients of biodiversity (De Deyn \& Van der Putten, 2005) and operate over a hierarchy of temporal scales (Bardgett, Bowman, Kaufmann \& Schmidt, 2005). Small spatial and temporal scale experimental manipulations (e.g. Gould et al., 2016; León-Sánchez et al., 2018), therefore, may not truly capture the complexities or multifunctionality of aboveground-belowground processes (De Deyn \& Van der Putten, 2005), which also pose a challenge to traditional modelling approaches.

To overcome the challenge of integrating network ecology research into macroecology, we encourage the use of modelling approaches that facilitate complex interactions and pathways between multiple variable types (Kissling \& Schleuning, 2015). For soil systems in particular, it is important to develop methods, such as correlation networks and structural equation models (SEMs), that emphasise biotic interactions but also include environmental effects, e.g. through latent and composite variables, to study causal mechanisms involving variables that are difficult to measure at a spatial scale relevant for soil organisms, or themselves exhibit complex interactions (e.g. as seen for soil fertility in Siciliano et al., 2014). SEMs are a useful correlative approach that can be easily implemented and characterise complex pathways at the ecosystem level, including the complex interaction networks and feedback loops observed in soil-to-aboveground systems (Eisenhauer, Bowker, Grace \& Powell., 2015). Grace 
et al. (2010) present SEMs as an approach to address the challenge of eliciting generalisable patterns,

467 such as those sought in macroecology, from heterogeneous system components. For example, SEMs have been used to partition causal influences and determine the direct and indirect relationships between geographic variables, soil characteristics, plant productivity/diversity and soil diversity at both the continental and global scale for soil bacteria and fungi (Tedersoo et al., 2014; DelgadoBaquerizo, Powell et al., 2017), as well as to determine the causal mechanisms underlying ecosystem functioning (Eisenhauer, Reich \& Isbell, 2012) and food web stability (De Vries et al., 2012). They, therefore, provide a useful tool for soil scientists and macroecologists to combine biotic and abiotic factors into studies of causal patterns of soil diversity and functioning.

\section{Abiotic considerations}

\section{Climate and microclimate}

477 Fine-scale spatial structuring of soil species may occur where the macroscopic environment appears uniform (Nielsen et al., 2010; Caruso, Taormina \& Migliorini, 2012). For example, the spatial structure of grass tussocks in pasture alter the microclimate of the soil which impacts earthworm diversity (Mathieu et al., 2009). To model soil biodiversity, therefore, measurement of environmental heterogeneity is required at fine scales (e.g. measuring and modelling microclimates). Microclimate modelling can be expanded to the macro-scale by using gridded continental-scale soil and weather data to accurately predict hourly local microclimates at multiple soil depths using a mechanistic modelling framework (Kearney et al. 2014). Microclimate modelling has become more accessible through advances in remote sensing, e.g. LiDAR, to quantify environmental covariates at high resolutions (Lembrechts, Nijs \& Lenoir, 2019), and development of freely available software and code, e.g. the R package microclima (Maclean et al. 2019). Furthermore, combining microclimate modelling frameworks with soil moisture simulation algorithms can provide accurate, high resolution soil moisture estimates for entire continents (Kearney \& Maino, 2018). Moving beyond simple correlative models towards mechanistic modelling is being encouraged within the SDM literature 
491 (Buckley et al., 2010) and offers a promising alternative for predicting distributions of soil organisms

492 in particular, where small-scale spatial and temporal heterogeneity of the environment is often more

493 important than large-scale climatic variables (Dauber et al., 2005; Kearney et al., 2014).

\section{Geodiversity and pedodiversity}

495 Environmental factors other than climate are likely to be particularly ecologically relevant

496

497

498

499

500

501

502

503

504

505

506

507

508

509

510

511

512

513

514

515 determinants of species distributions belowground, and geological as well as biological resources should be considered (Ibáñez, Krasilnikov and Saldaña, 2012). The incorporation of soil types, texture and geochemistry (i.e. pedodiversity) into analyses of soil biodiversity has been encouraged (Parker, 2010) and carried out at the local scale (e.g. earthworms, Decaëns \& Rossi, 2008; Solomou et al., 2013; bacteria, Ranjard et al., 2010), as well as larger scales for earthworms (Rutgers et al., 2016). Integration of point level soil characteristics data, such as the LUCAS dataset (Orgiazzi, Ballabio, Panagos, Jones \& Fernández-Ugalde, 2018), can provide environmental information at coarse resolutions ( $2 \mathrm{~km} \times 2 \mathrm{~km})$ but large geographical extents, i.e. continental, whilst machine learning techniques combining soil and earth observation data can provide global gridded soil information at a resolution of $250 \mathrm{~m}$ x $250 \mathrm{~m}$ (Hengl et al. 2017). The latter has recently been incorporated into models of global earthworm diversity, but did not appear important in shaping community diversity, likely due to the scale of the study (Phillips et al. 2019). Diversity of geophysical properties (i.e. geodiversity) and pedodiversity provide opportunities to scale up soil biodiversity analyses. Spatial soil information science has become particularly advanced and sophisticated statistical tools to predict spatial patterns of soil properties (including salinity, soil moisture content and soil bulk density) offer novel opportunities to obtain predictor variables of soil organism distributions and diversity (Padarian et al., 2020). We may expect an obvious link between geodiversity or pedodiversity variables and soil biodiversity, however, incorporation of these factors into models has often been restricted to plants (e.g. Tukiainen et al., 2017; Bailey et al., 2018), although geochemical variables including salinity and soil nitrate variables have been linked to nematode abundances in Antarctica (Poage et al., 2008), and 
global soil bacteria richness peaks in neutral soils (Fierer \& Jackson, 2006). Pedodiversity analyses,

517 therefore, offer an exciting opportunity to overcome a severe gap in soil macroecological research.

\section{Recommendations and Future Perspectives}

519 Although there has been a recent surge in broad-scale papers mapping soil biodiversity, the field of soil macroecology needs to be advanced by emphasising process over pattern (Hanson et al., 2012). Soils differ from aboveground systems in ways that have been challenging for the generalisations dear to macroecology: they are characterised by high heterogeneity making data collection and analysis difficult, and are inhabited by organisms that are incredibly variable in size and trophic roles, while being poorly known taxonomically. We have discussed how recent methods and data management initiatives might help soil ecologists and macroecologists to collaborate more often. We demonstrate that methodological considerations need to be made at all stages of investigation spanning delimitation and quantification of diversity, spatial and temporal context, biotic considerations and abiotic properties, and propose multiple approaches to deal with challenges within each of these sets of considerations (Fig. 2). Most of these methods are applicable (and some already applied) aboveground, but are particularly suited to address the incredible spatial and temporal variability of biotic and abiotic conditions, combined with the scarcity of data, in soils. When these are overcome, we expect that new rules may emerge from macroecological analysis of soils.

\section{References}

Aguilar-Trigueros, C. A., Hempel, S., Powell, J. R., Anderson, I. C., Antonovics, J., Bergmann, J., ... Rillig, M. C. (2015). Branching out: Towards a trait-based understanding of fungal ecology. functional composition. Ecology Letters, 18(8), 834-843. 
Amir, A., McDonald, D., Navas-Molina, J. A., Kopylova, E., Morton, J. T., Zech Xu, Z., ... Knight, R. (2017). Deblur Rapidly Resolves Single-Nucleotide Community Sequence Patterns. MSystems, 2(2), e00191-16.

Archer, S. D. J., Lee, K. C., Caruso, T., Maki, T., Lee, C. K., Cary, S. C., ... Pointing, S. B. (2019). Airborne microbial transport limitation to isolated Antarctic soil habitats. Nature Microbiology, 4(6), 925-932.

Arsène-Ploetze, F., Bertin, P. N., \& Carapito, C. (2015). Proteomic tools to decipher microbial community structure and functioning. Environmental Science and Pollution Research International, 22(18), 13599-13612.

Bach, E. M., Williams, R. J., Hargreaves, S. K., Yang, F., \& Hofmockel, K. S. (2018). Greatest soil microbial diversity found in micro-habitats. Soil Biology and Biochemistry, 118(January), 217226.

Bahram, M., Hildebrand, F., Forslund, S. K., Anderson, J. L., Soudzilovskaia, N. A., Bodegom, P. M., ... Bork, P. (2018). Structure and function of the global topsoil microbiome. Nature, 560(7717), 233-237.

Bailey, J. J., Boyd, D. S., \& Field, R. (2018). Models of upland species' distributions are improved by accounting for geodiversity. Landscape Ecology, 33(12), 2071-2087.

Barbaro, L., \& Van Halder, I. (2009). Linking bird, carabid beetle and butterfly life-history traits to habitat fragmentation in mosaic landscapes. Ecography, 32(2), 321-333.

Barberán, A., Bates, S. T., Casamayor, E. O., \& Fierer, N. (2012). Using network analysis to explore co-occurrence patterns in soil microbial communities. ISME Journal, 6(2), 343-351.

Bardgett, R. D., Bowman, W. D., Kaufmann, R., \& Schmidt, S. K. (2005). A temporal approach to linking aboveground and belowground ecology. Trends in Ecology and Evolution, 20(11), 634641. 
Bardgett, R. D., \& Wardle, D. A. (2010). Aboveground-belowground linkages: biotic interactions, ecosystem processes, and global change. Oxford University Press.

Barrios-O’Neill, D., Kelly, R., Dick, J. T. A., Ricciardi, A., Macisaac, H. J., \& Emmerson, M. C. (2016). On the context-dependent scaling of consumer feeding rates. Ecology Letters, 19(6), $668-678$.

Beale, C. M., Lennon, J. J., Yearsley, J. M., Brewer, M. J., \& Elston, D. a. (2010). Regression analysis of spatial data. Ecology Letters, 13(2), 246-64.

Bienert, F., De Danieli, S., Miquel, C., Coissac, E., Poillot, C., Brun, J. J., \& Taberlet, P. (2012). Tracking earthworm communities from soil DNA. Molecular Ecology, 21(8), 2017-2030.

Bik, H. M., Porazinska, D. L., Creer, S., Caporaso, J. G., Knight, R., \& Thomas, W. K. (2012, April). Sequencing our way towards understanding global eukaryotic biodiversity. Trends in Ecology and Evolution.

Bishop, T. R., Robertson, M. P., Gibb, H., van Rensburg, B. J., Braschler, B., Chown, S. L., ... Parr, C. L. (2016). Ant assemblages have darker and larger members in cold environments. Global Ecology and Biogeography, 25(12), 1489-1499.

Blagodatskaya, E., \& Kuzyakov, Y. (2013). Active microorganisms in soil: Critical review of estimation criteria and approaches. Soil Biology and Biochemistry, 67, 192-211.

Bonfante, P., \& Genre, A. (2010). Mechanisms underlying beneficial plant-fungus interactions in mycorrhizal symbiosis. Nature Communications, 1(48).

Buckley, L. B., Urban, M. C., Angilletta, M. J., Crozier, L. G., Rissler, L. J., \& Sears, M. W. (2010). Can mechanism inform species' distribution models? Ecology Letters, 13(8), 1041-1054.

Butt, K. R., \& Lowe, C. N. (2007). Presence of earthworm species within and beneath Lumbricus terrestris (L.) middens. European Journal of Soil Biology, 43(SUPPL. 1), 57-60. 
Caldwell, B. A. (2005). Enzyme activities as a component of soil biodiversity: A review.

$$
\text { Pedobiologia, 49(6), 637-644. }
$$

Callahan, B. J., McMurdie, P. J., \& Holmes, S. P. (2017). Exact sequence variants should replace operational taxonomic units in marker-gene data analysis. ISME Journal, 11(12), 2639-2643.

Cameron, E. K., Decaëns, T., Lapied, E., Porco, D., \& Eisenhauer, N. (2016). Earthworm databases and ecological theory: Synthesis of current initiatives and main research directions. Applied Soil Ecology, 104, 85-90.

Cameron, E. K., Martins, I. S., Lavelle, P., Mathieu, J., Tedersoo, L. 2, Gottschall, F., ... Eisenhauer, N. (2018). Global gaps in soil biodiversity data. Nature Ecology \& Evolution, 2, 1042-1043.

Carini, P., Marsden, P. J., Leff, J. W., Morgan, E., Strickland, M. S., \& Fierer, N. (2016). Relic DNA is abundant in soil and obscures estimates of soil microbial diversity. Nature Microbiology, 2, 16242.

Caruso, T., Hogg, I. D., Carapelli, A., Frati, F., \& Bargagli, R. (2009). Large-scale spatial patterns in the distribution of Collembola (Hexapoda) species in Antarctic terrestrial ecosystems. Journal of Biogeography, 36(5), 879-886.

Caruso, T., Schaefer, I., Monson, F., \& Keith, A. M. (2019). Oribatid mites show how climate and latitudinal gradients in organic matter can drive large-scale biodiversity patterns of soil communities. Journal of Biogeography, 46(3), 611-620.

Caruso, T., Taormina, M., \& Migliorini, M. (2012). Relative role of deterministic and stochastic determinants of soil animal community : a spatially explicit analysis of oribatid mites. Journal of Animal Ecology, 81(1), 214-221.

Crowther, T. W., van den Hoogen, J., Wan, J., Mayes, M. A., Keiser, A. D., Mo, L., .. Maynard, D. S. (2019). The global soil community and its influence on biogeochemistry. Science, 365(6455), eaav0550. 
Dauber, J., Purtauf, T., Allspach, A., Frisch, J., Voigtländer, K., \& Wolters, V. (2005). Local vs. landscape controls on diversity: A test using surface-dwelling soil macroinvertebrates of differing mobility. Global Ecology and Biogeography, 14(3), 213-221.

Davison, J., Moora, M., Opik, M., Adholeya, A., Ainsaar, L., Ba, A., ... Zobel, M. (2015). Global assessment of arbuscular mycorrhizal fungus diversity reveals very low endemism. Science, 349(6251), 970-973.

Dawson, S. K., Boddy, L., Halbwachs, H., Bässler, C., Andrew, C., Crowther, T. W., ... Jönsson, M. (2019). Handbook for the measurement of macrofungal functional traits: A start with basidiomycete wood fungi. Functional Ecology, 33(3), 372-387.

De Deyn, G. B., \& Van Der Putten, W. H. (2005). Linking aboveground and belowground diversity. Trends in Ecology and Evolution, 20(11), 625-633.

De Laender, F., Rohr, J. R., Ashauer, R., Baird, D. J., Berger, U., Eisenhauer, N., ... Van den Brink, P. J. (2016). Reintroducing Environmental Change Drivers in Biodiversity-Ecosystem Functioning Research. Trends in Ecology and Evolution, 31(12), 905-915.

De Vries, F. T., Thebault, E., Liiri, M., Birkhofer, K., Tsiafouli, M. A., Bjornlund, L., ... Bardgett, R. D. (2013). Soil food web properties explain ecosystem services across European land use systems. Proceedings of the National Academy of Sciences, 110(35), 14296-14301.

De Vries, F. T., Liiri, M. E., Bjørnlund, L., Bowker, M. A., Christensen, S., Setälä, H. M., \& Bardgett, R. D. (2012). Land use alters the resistance and resilience of soil food webs to drought. Nature Climate Change, 2(4), 276-280.

Decaëns, T., Lavelle, P., \& Jiménez, J. J. (2008). Priorities for conservation of soil animals. $C A B$ Reviews: Perspectives in Agriculture, Veterinary Science, Nutrition and Natural Resources, 3(014), 1-18. 
Decaëns, T. (2010). Macroecological patterns in soil communities. Global Ecology and Biogeography, 19(3), 287-302.

Decaëns, T., \& Rossi, J. P. (2008). Spatio-temporal structure of earthworm community and soil heterogeneity in a tropical pasture. Ecography, 24(6), 671-682.

Dechesne, A., Pallud, C., Debouzie, D., Flandrois, J. ., Vogel, T. ., Gaudet, J. ., \& Grundmann, G. . (2003). A novel method for characterizing the microscale 3D spatial distribution of bacteria in soil. Soil Biology and Biochemistry, 35(12), 1537-1546.

Deiner, K., Bik, H. M., Mächler, E., Seymour, M., Lacoursière-Roussel, A., Altermatt, F., ... Bernatchez, L. (2017). Environmental DNA metabarcoding: Transforming how we survey animal and plant communities. Molecular Ecology, 26(21), 5872-5895.

Delgado-Baquerizo, M., Oliverio, A. M., Brewer, T. E., Benavent-González, A., Eldridge, D. J., Bardgett, R. D., ... Fierer, N. (2018). A global atlas of the dominant bacteria found in soil. Science, 359(6373), 320-325.

Delgado-Baquerizo, M., Powell, J. R., Hamonts, K., Reith, F., Mele, P., Brown, M. V, ... Bissett, A. (2017). Circular linkages between soil biodiversity, fertility and plant productivity are limited to topsoil at the continental scale. New Phytologist, 215(3), 1186-1196.

Delgado-Baquerizo, M., Reich, P. B., Trivedi, C., Eldridge, D. J., Abades, S., Alfaro, F. D., ... Singh, B. K. (2020). Multiple elements of soil biodiversity drive ecosystem functions across biomes. Nature Ecology \& Evolution, 4(2), 210-220.

Dirilgen, T., Juceviča, E., Melecis, V., Querner, P., \& Bolger, T. (2018). Analysis of spatial patterns informs community assembly and sampling requirements for Collembola in forest soils. Acta Oecologica, 86, 23-30. 
Dowle, E.J., Pochon, X., C. Banks, J., Shearer, K. and Wood, S.A., 2016. Targeted gene enrichment and high-throughput sequencing for environmental biomonitoring: A case study using freshwater macroinvertebrates. Molecular Ecology Resources, 16(5), 1240-1254.

Duffy, G., \& Chown, S. (2017). Explicitly integrating a third dimension in marine species distribution modelling. Marine Ecology Progress Series, 564, 1-8.

Eilers, K. G., Debenport, S., Anderson, S., \& Fierer, N. (2012). Digging deeper to find unique microbial communities: The strong effect of depth on the structure of bacterial and archaeal communities in soil. Soil Biology and Biochemistry, 50, 58-65.

Eisenhauer, N., Antunes, P. M., Bennett, A. E., Birkhofer, K., Bissett, A., Bowker, M. A., ... Powell, J. R. (2017). Priorities for research in soil ecology. Pedobiologia, 63, 1-7.

Eisenhauer, N., Bowker, M. A., Grace, J. B., \& Powell, J. R. (2015). From patterns to causal understanding: Structural equation modeling (SEM) in soil ecology. Pedobiologia, 58(2-3), 6572.

Eisenhauer, N., Reich, P. B., \& Isbell, F. (2012). Decomposer diversity and identity influence plant diversity effects on ecosystem functioning. Ecology, 93(10), 2227-2240.

Elith, J., \& Leathwick, J. R. (2009). Species Distribution Models: Ecological explanation and prediction across space and time. Annual Review of Ecology, Evolution, and Systematics, 40, $677-697$.

Ettema, C. H., \& Wardle, D. A. (2002). Spatial soil ecology. Trends in Ecology \& Evolution, 17(4), $177-183$.

Evans, K. L., Newson, S. E., Storch, D., Greenwood, J. J. D., \& Gaston, K. J. (2008). Spatial scale, abundance and the species-energy relationship in British birds. Journal of Animal Ecology, 77(2), 395-405. 
Fierer, N., Leff, J. W., Adams, B. J., Nielsen, U. N., Bates, S. T., Lauber, C. L., .. Caporaso, J. G. (2012). Cross-biome metagenomic analyses of soil microbial communities and their functional attributes. Proceedings of the National Academy of Sciences, 109(52), 21390-21395.

Fierer, N. (2017). Embracing the unknown: disentangling the complexities of the soil microbiome. Nature Reviews Microbiology, 15(10), 579-590.

Fierer, N., \& Jackson, R. B. (2006). The diversity and biogeography of soil bacterial communities. Proceedings of the National Academy of Sciences, 103(3), 626-631.

Fierer, N., \& Lennon, J. T. (2011). The generation and maintenance of diversity in microbial communities. American Journal of Botany, 98(3), 439-448.

Fierer, N., Schimel, J. P., \& Holden, P. A. (2003). Variations in microbial community composition through two soil depth profiles. Soil Biology and Biochemistry, 35(1), 167-176.

Finlay BJ. (2002). Global dispersal of free-living microbial eukaryote species. Science, 296(5570), $1061-1063$.

Franklin, J. (2010). Moving beyond static species distribution models in support of conservation biogeography. Diversity and Distributions, 16(3), 321-330.

Gaston, K. J. (2000). Global patterns in biodiversity. Nature, 405(6783), 220-227.

Geisen, S., Briones, M. J. I., Gan, H., Behan-Pelletier, V. M., Friman, V.-P., de Groot, G. A., ... Wall, D. H. (2019). A methodological framework to embrace soil biodiversity. Soil Biology and Biochemistry, 136, 107536.

Gerard, B. M. (1967). Factors affecting earthworms in pastures. Journal of Animal Ecology, 36(1), $235-252$. 
Gould, I. J., Quinton, J. N., Weigelt, A., De Deyn, G. B., \& Bardgett, R. D. (2016). Plant diversity and root traits benefit physical properties key to soil function in grasslands. Ecology Letters, 19(9), $1140-1149$.

Grace, J. B., Michael Anderson, T., Han, O., \& Scheiner, S. M. (2010). On the specification of structural equation models for ecological systems. Ecological Monographs, 80(1), 67-87.

Grundmann, G. L., \& Debouzie, D. (2000). Geostatistical analysis of the distribution of NH $\$ 4$ and NO 2 -oxidizing bacteria and serotypes at the millimeter scale along a soil transect. FEMS Microbiology Ecology, 34(3), 57-62.

Grundmann, G. L., Dechesne, A., Bartoli, F., Flandrois, J. P., Chassé, J. L., \& Kizungu, R. (2001). Spatial Modeling of Nitrifier Microhabitats in Soil. Soil Science Society of America Journal, 65(6), 1709-1716.

Gumiere, T., Durrer, A., Bohannan, B. J. M., \& Andreote, F. D. (2016). Biogeographical patterns in fungal communities from soils cultivated with sugarcane. Journal of Biogeography, 43(10), 2016-2026.

Hanson, C. A., Fuhrman, J. A., Horner-Devine, M. C., \& Martiny, J. B. H. (2012). Beyond biogeographic patterns: Processes shaping the microbial landscape. Nature Reviews Microbiology, 10(7), 497-506.

Hedde, M., Pey, B., Auclerc, A., Capowiez, Y., Cluzeau, D., et al.. BETSI, a complete framework for studying soil invertebrate functional traits. XVI ICSZ - International Colloquium on Soil Zoology, Aug 2012, Coimbra, Portugal. 2012.

Heemsbergen, D. A., Berg, M. P., Loreau, J. R., van Hal, J. R., Faber, J. H., \& Verhoef, H. A. (2004). Biodiversity effects on soil processes explained by interspecific functional dissimilarity. Science, 306(5698), 1019-1020. 
Hendershot, J. N., Read, Q. D., Henning, J. A., Sanders, N. J., \& Classen, A. T. (2017). Consistently inconsistent drivers of microbial diversity and abundance at macroecological scales. Ecology, 98(7), 1757-1763.

Hengl, T., De Jesus, J. M., Heuvelink, G. B. M., Gonzalez, M. R., Kilibarda, M., Blagotić, A., ... Kempen, B. (2017). SoilGrids250m: Global gridded soil information based on machine learning. PLoS ONE, 12(2), e0169748.

Hooper, D. U., Chapin, F. S., Ewel, J. J., Hector, A., Inchausti, P., Lavorel, S., ... Wardle, D. A. (2005). Effects of biodiversity on ecosystem functioning: A consensus of current knowledge. Ecological Monographs, 75(1), 3-35.

Ibáñez, J. J., Krasilnikov, P. V., \& Saldaña, A. (2012). Archive and refugia of soil organisms: Applying a pedodiversity framework for the conservation of biological and non-biological heritages. Journal of Applied Ecology, 49(6), 1267-1277.

Ínceoğlu, Ö., Hoogwout, E. F., Hill, P., \& Van Elsas, J. D. (2010). Effect of DNA extraction method on the apparent microbial diversity of soil. Applied and Environmental Microbiology, 76(10), $3378-3382$.

Jackson, H. B., \& Fahrig, L. (2012). What size is a biologically relevant landscape? Landscape Ecology, 27(7), 929-941.

Jiménez, J. J., Decaëns, T., Lavelle, P., \& Rossi, J.-P. (2014). Dissecting the multi-scale spatial relationship of earthworm assemblages with soil environmental variability. BMC Ecology, 14(1), 26.

Joschko, M., Fox, C. A., Lentzsch, P., Kiesel, J., Hierold, W., Krück, S., \& Timmer, J. (2006). Spatial analysis of earthworm biodiversity at the regional scale. Agriculture, Ecosystems and Environment, 112(4), 367-380. https://doi.org/10.1016/j.agee.2005.08.026 
Judas, M. (1988). The species-area relationship of European lumbricidade (annelida, oligochaeta). Oecologia, 76(4), 579-587.

Kearney, M. R., \& Maino, J. L. (2018). Can next-generation soil data products improve soil moisture modelling at the continental scale? An assessment using a new microclimate package for the $\mathrm{R}$ programming environment. Journal of Hydrology, 561, 662-673.

Kearney, M. R., Shamakhy, A., Tingley, R., Karoly, D. J., Hoffmann, A. A., Briggs, P. R., \& Porter, W. P. (2014). Microclimate modelling at macro scales: a test of a general microclimate model integrated with gridded continental-scale soil and weather data. Methods in Ecology and Evolution, 5(3), 273-286.

King, R. A., Tibble, A. L., \& Symondson, W. O. C. (2008). Opening a can of worms: Unprecedented sympatric cryptic diversity within British lumbricid earthworms. Molecular Ecology, 17(21), 4684-4698.

Kissling, W. D., \& Schleuning, M. (2015). Multispecies interactions across trophic levels at macroscales: Retrospective and future directions. Ecography, 38(4), 346-357.

Kivlin, S. N., Hawkes, C. V., \& Treseder, K. K. (2011). Global diversity and distribution of arbuscular mycorrhizal fungi. Soil Biology and Biochemistry, 43(11), 2294-2303.

Koyama, A., Maherali, H., \& Antunes, P. M. (2019). Plant geographic origin and phylogeny as potential drivers of community structure in root-inhabiting fungi. Journal of Ecology, 107(4), $1720-1736$.

Krause, S., Le Roux, X., Niklaus, P. A., Van Bodegom, P. M., Lennon, J. T., Bertilsson, S., ... Bodelier, P. L. E. (2014). Trait-based approaches for understanding microbial biodiversity and ecosystem functioning. Frontiers in Microbiology, 5(MAY), 1-10.

Kuzyakov, Y., \& Blagodatskaya, E. (2015). Microbial hotspots and hot moments in soil: Concept \& review. Soil Biology and Biochemistry, 83, 184-199. 
Ladau, J., \& Eloe-Fadrosh, E. A. (2019). Spatial, Temporal, and Phylogenetic Scales of Microbial Ecology. Trends in Microbiology, 27(8), 662-669.

Lemanceau, P. (2011). EcoFINDERS: characterizing biodiversity and soil functioning in Europe. 23 partners from 10 European countries and China. Biofutur, 326, 56-58.

Lembrechts, J., Nijs, I., \& Lenoir, J. (2018). Incorporating microclimate into species distribution models. Ecography, 42(7), 1267-1279.

Lennon, J. T., Muscarella, M. E., Placella, S. A., \& Lehmkuhl, B. K. (2018). How, When, and Where Relic DNA Affects Microbial Diversity. MBio, 9(3), e00637-18

León-Sánchez, L., Nicolás, E., Goberna, M., Prieto, I., Maestre, F. T., \& Querejeta, J. I. (2018). Poor plant performance under simulated climate change is linked to mycorrhizal responses in a semiarid shrubland. Journal of Ecology, 106(3), 960-976.

Lindo, Z., \& Winchester, N. N. (2006). A comparison of microarthropod assemblages with emphasis on oribatid mites in canopy suspended soils and forest floors associated with ancient western redcedar trees. Pedobiologia, 50(1), 31-41.

Maclean, I. M. D., Mosedale, J. R., \& Bennie, J. J. (2019). Microclima: An R package for modelling meso- and microclimate. Methods in Ecology and Evolution, 10(2), 280-290.

Marchán, D. F., Refoyo, P., Novo, M., Fernández, R., Trigo, D., \& Díaz Cosín, D. J. (2015). Predicting soil micro-variables and the distribution of an endogeic earthworm species through a model based on large-scale variables. Soil Biology and Biochemistry, 81, 124-127.

Maron, P. A., Ranjard, L., Mougel, C., \& Lemanceau, P. (2007). Metaproteomics: A new approach for studying functional microbial ecology. Microbial Ecology, 53(3), 486-493. 
Martay, B., \& Pearce-Higgins, J. W. (2018). Using data from schools to model variation in soil invertebrates across the UK: The importance of weather, climate, season and habitat. Pedobiologia, 67, 1-9.

Mathieu, J., Caro, G., \& Dupont, L. (2018). Methods for studying earthworm dispersal. Applied Soil Ecology, 123, 339-344.

Mathieu, J., Grimaldi, M., Jouquet, P., Rouland, C., Lavelle, P., Desjardins, T., \& Rossi, J. P. (2009). Spatial patterns of grasses influence soil macrofauna biodiversity in Amazonian pastures. Soil Biology and Biochemistry, 41(3), 586-593.

Maynard, D. S., Bradford, M. A., Covey, K. R., Lindner, D., Glaeser, J., Talbert, D. A., ... Crowther, T. W. (2019). Consistent trade-offs in fungal trait expression across broad spatial scales. Nature Microbiology, 4(5), 846-853.

McGill, B. J. (2019). The what, how and why of doing macroecology. Global Ecology and Biogeography, 28(1), 6-17.

Meentemeyer, R. K., Anacker, B. L., Mark, W., \& Rizzo, D. M. (2008). Early detection of emerging forest disease using dispersal estimation and ecological niche modeling. Ecological Applications, 18(2), 377-390.

Meynard, C. N., Devictor, V., Mouillot, D., Thuiller, W., Jiguet, F., \& Mouquet, N. (2011). Beyond taxonomic diversity patterns: how do $\alpha, \beta$ and $\gamma$ components of bird functional and phylogenetic diversity respond to environmental gradients across France? Global Ecology and Biogeography, 20(6), 893-903.

Montagna, M., Berruti, A., Bianciotto, V., Cremonesi, P., Giannico, R., Gusmeroli, F., ... Gandini, G. (2018). Differential biodiversity responses between kingdoms (plants, fungi, bacteria and metazoa) along an Alpine succession gradient. Molecular Ecology, 27(18), 3671-3685. 
Morriën, E. (2016). Understanding soil food web dynamics, how close do we get? Soil Biology and Biochemistry, 102, 10-13.

Mysara, M., Vandamme, P., Props, R., Kerckhof, F. M., Leys, N., Boon, N., .. Monsieurs, P. (2017). Reconciliation between operational taxonomic units and species boundaries. FEMS Microbiology Ecology, 93(4), 1-12.

Nekola, J. C., \& White, P. S. (1999). The distance decay of similarity in biogeography and ecology. Journal of Biogeography 26, 867-878.

Nesme, J., Achouak, W., Agathos, S. N., Bailey, M., Baldrian, P., Brunel, D., ... Simonet, P. (2016). Back to the Future of Soil Metagenomics. Frontiers in Microbiology, 7, 1-5.

Newbold, T., Hudson, L. N., Hill, S. L. L., Contu, S., Lysenko, I., Senior, R. A., ... Purvis, A. (2015). Global effects of land use on local terrestrial biodiversity. Nature, 520(7545), 45-50.

Newman, E. A., Kennedy, M. C., Falk, D. A., \& McKenzie, D. (2019). Scaling and Complexity in Landscape Ecology. Frontiers in Ecology and Evolution, 7, 293.

Nielsen, U. N., Osler, G. H. R., Campbell, C. D., Neilson, R., Burslem, D. F. R. P., \& van der Wal, R. (2010). The enigma of soil animal species diversity revisited: The role of small-scale heterogeneity. PLoS ONE, 5(7), 26-28.

Nobis, M. P., \& Normand, S. (2014). KISSMig - a simple model for R to account for limited migration in analyses of species distributions. Ecography, 37(12), 1282-1287.

Noguez, A. M., Arita, H. T., Escalante, A. E., Forney, L. J., García-Oliva, F., \& Souza, V. (2005). Microbial macroecology: Highly structured prokaryotic soil assemblages in a tropical deciduous forest. Global Ecology and Biogeography, 14(3), 241-248. 
O’Brien, S. L., Gibbons, S. M., Owens, S. M., Hampton-Marcell, J., Johnston, E. R., Jastrow, J. D., ... Antonopoulos, D. A. (2016). Spatial scale drives patterns in soil bacterial diversity. Environmental Microbiology, 18(6), 2039-2051.

Öpik, M., Vanatoa, A., Vanatoa, E., Moora, M., Davison, J., Kalwij, J. M., ... Zobel, M. (2010). The online database MaarjAM reveals global and ecosystemic distribution patterns in arbuscular mycorrhizal fungi (Glomeromycota). New Phytologist, 188(1), 223-241.

Orgiazzi, A., Ballabio, C., Panagos, P., Jones, A., \& Fernández-Ugalde, O. (2018). LUCAS Soil, the largest expandable soil dataset for Europe: a review. European Journal of Soil Science, 69(1), $140-153$.

Orgiazzi, A., Dunbar, M. B., Panagos, P., de Groot, G. A., \& Lemanceau, P. (2015). Soil biodiversity and DNA barcodes: opportunities and challenges. Soil Biology and Biochemistry, 80, 244-250.

Padarian, J., Minasny, B., \& McBratney, A. B. (2020). Machine learning and soil sciences: a review aided by machine learning tools. SOIL, 6(1), 35-52.

Palm, J., van Schaik, N. L. M. B., \& Schröder, B. (2013). Modelling distribution patterns of anecic, epigeic and endogeic earthworms at catchment-scale in agro-ecosystems. Pedobiologia, 56(1), $23-31$.

Pansu, J., De Danieli, S., Puissant, J., Gonzalez, J.-M., Gielly, L., Cordonnier, T., ... Cécillon, L. (2015). Landscape-scale distribution patterns of earthworms inferred from soil DNA. Soil Biology and Biochemistry, 83, 100-105.

Papp, K., Mau, R. L., Hayer, M., Koch, B. J., Hungate, B. A., \& Schwartz, E. (2018). Quantitative stable isotope probing with $\mathrm{H} 218 \mathrm{O}$ reveals that most bacterial taxa in soil synthesize new ribosomal RNA. The ISME Journal, 18-20. 
Pärtel, M., Öpik, M., Moora, M., Tedersoo, L., Szava-Kovats, R., Rosendahl, S., ... Zobel, M. (2017). Historical biome distribution and recent human disturbance shape the diversity of arbuscular mycorrhizal fungi. New Phytologist, 227-238.

Pasternak, Z., Al-Ashhab, A., Gatica, J., Gafny, R., Avraham, S., Minz, D., ... Jurkevitch, E. (2013). Spatial and Temporal Biogeography of Soil Microbial Communities in Arid and Semiarid Regions. PLoS ONE, 8(7), e69705.

Pausch, J., Hünninghaus, M., Kramer, S., Scharroba, A., Scheunemann, N., Butenschoen, O., Marhan, S., Bonkowski, M., Kandeler, E., Scheu, S., Kuzyakov, Y., \& Ruess, L. (2018). Carbon budgets of top- and subsoil food webs in an arable system. Pedobiologia, 69, 29-33.

Pawar, S., Dell, A. I., Lin, T., Wieczynski, D. J., \& Savage, V. M. (2019). Interaction dimensionality scales up to generate bimodal consumer-resource size-ratio distributions in ecological communities. Frontiers in Ecology and Evolution, 7, 1-11.

Peay, K. G., Bruns, T. D., Kennedy, P. G., Bergemann, S. E., \& Garbelotto, M. (2007). A strong species-area relationship for eukaryotic soil microbes: Island size matters for ectomycorrhizal fungi. Ecology Letters, 10(6), 470-480.

Peay, K. G., Garbelotto, M., \& Bruns, T. D. (2010). Evidence of dispersal limitation in soil microorganisms: Isolation reduces species richness on mycorrhizal tree islands. Ecology, 91(12), $3631-3640$.

Peay, K. G., Schubert, M. G., Nguyen, N. H., \& Bruns, T. D. (2012). Measuring ectomycorrhizal fungal dispersal: macroecological patterns driven by microscopic propagules. Molecular Ecology, 21(16), 4122-4136.

Pellissier, L., Niculita-Hirzel, H., Dubuis, A., Pagni, M., Guex, N., Ndiribe, C., ... Guisan, A. (2014). Soil fungal communities of grasslands are environmentally structured at a regional scale in the Alps. Molecular Ecology, 23(17), 4274-4290. 
Philippot, L., Ritz, K., Pandard, P., Hallin, S., \& Martin-Laurent, F. (2012). Standardisation of methods in soil microbiology: Progress and challenges. FEMS Microbiology Ecology, 82(1), 110.

Phillips, H. R. P., Guerra, C. A., Bartz, M. L. C., Briones, M. J. I., Brown, G., Crowther, T. W., ... Eisenhauer, N. (2019). Global distribution of earthworm diversity. Science, 366(6464), 480485.

Phillips, H. R. P., Cameron, E. K., Ferlian, O., Türke, M., Winter, M., \& Eisenhauer, N. (2017). Red list of a black box. Nature Ecology \& Evolution, 1(4), 0103.

Pickles, B. J., Genney, D. R., Potts, J. M., Lennon, J. J., Anderson, I. C., \& Alexander, I. J. (2010). Spatial and temporal ecology of Scots pine ectomycorrhizas. New Phytologist, 186(3), 755-768.

Poage, M. A., Barrett, J. E., Virginia, R. A., \& Wall, D. H. (2014). The Influence of Soil Geochemistry on Nematode Distribution, McMurdo Dry Valleys, on Nematode Distri. Arctic, Antarctic and Alpine Research, 7(4), 331-340.

Pollock, L. J., Tingley, R., Morris, W. K., Golding, N., O’Hara, R. B., Parris, K. M., .. Mccarthy, M. A. (2014). Understanding co-occurrence by modelling species simultaneously with a Joint Species Distribution Model (JSDM). Methods in Ecology and Evolution, 5(5), 397-406.

Powell, J. R., \& Rillig, M. C. (2018). Biodiversity of arbuscular mycorrhizal fungi and ecosystem function. New Phytologist, 220(4), 1059-1075.

Prosser, J. I. (2015). Dispersing misconceptions and identifying opportunities for the use of "omics" in soil microbial ecology. Nature Reviews Microbiology, 13, 439-446.

Ramirez, K. S., Knight, C. G., de Hollander, M., Brearley, F. Q., Constantinides, B., Cotton, A., ... de Vries, F. T. (2018). Detecting macroecological patterns in bacterial communities across independent studies of global soils. Nature Microbiology, 3(2), 189-196. 
Ramirez, K. S., Döring, M., Eisenhauer, N., Gardi, C., Ladau, J., Leff, J. W., ... Morgan, K. (2015). Toward a global platform for linking soil biodiversity data. Frontiers in Ecology and Evolution, $3(91), 1-7$.

Ramirez, K. S., Leff, J. W., Barberán, A., Bates, S. T., Betley, J., Thomas, W., ... Fierer, N. (2014). Biogeographic patterns in below-ground diversity in New York City’s Central Park are similar to those observed globally. Proceedings of the Royal Society B, 281(1795), 20141988..

Ranjard, L., Dequiedt, S., Jolivet, C., Saby, N. P. A., Thioulouse, J., Harmand, J., ... Lemanceau, P. (2009). Biogeography of soil microbial communities: A review and a description of the ongoing French national initiative. Sustainable Agriculture, 2, 857-865.

Rasmussen, P. U., Hugerth, L. W., Blanchet, F. G., Andersson, A. F., Lindahl, B. D., \& Tack, A. J. M. (2018). Multiscale patterns and drivers of arbuscular mycorrhizal fungal communities in the roots and root-associated soil of a wild perennial herb. New Phytologist, 220(4), 1248-1261.

Raymond, M. R., Wharton, D. A., \& Marshall, C. J. (2013). Factors determining nematode distributions at Cape Hallett and Gondwana station, Antarctica. Antarctic Science, 25(3), 347357.

Raynaud, X., \& Nunan, N. (2014). Spatial Ecology of Bacteria at the Microscale in Soil. PLoS ONE, 9(1), e87217.

Rodgers, D. J., \& Kitching, R. L. (1998). Vertical stratification of rainforest collembolan (Collembola: Insecta) assemblages: Description of ecological patterns and hypotheses concerning their generation. Ecography, 21(4), 392-400.

Rosenzweig, M. L. (1995). Species diversity in space and time. Cambridge University Press.

Rumpel, C., \& Kögel-Knabner, I. (2011). Deep soil organic matter-a key but poorly understood component of terrestrial C cycle. Plant and Soil, 338(1), 143-158. 
Ruppert, K. M., Kline, R. J., \& Rahman, M. S. (2019). Past, present, and future perspectives of environmental DNA (eDNA) metabarcoding: A systematic review in methods, monitoring, and applications of global eDNA. Global Ecology and Conservation, 17, e00547.

Rutgers, M., Orgiazzi, A., Gardi, C., Römbke, J., Jänsch, S., Keith, A. M., ... Zwart, D. de. (2016). Mapping earthworm communities in Europe. Applied Soil Ecology, 97, 98-111.

Rutgers, M., van Leeuwen, J. P., Vrebos, D., van Wijnen, H. J., Schouten, T., \& de Goede, R. G. M. (2019). Mapping Soil Biodiversity in Europe and the Netherlands. Soil Systems, 3(2), 39.

Sato, H., Tsujino, R., Kurita, K., Yokoyama, K., \& Agata, K. (2012). Modelling the global distribution of fungal species: New insights into microbial cosmopolitanism. Molecular Ecology, 21(22), 5599-5612.

Sayer, E. J., Wagner, M., Oliver, A. E., Pywell, R. F., James, P., Whiteley, A. S., \& Heard, M. S. (2013). Grassland management influences spatial patterns of soil microbial communities. Soil Biology and Biochemistry, 61, 61-68.

Schaefer, I., \& Caruso, T. (2019). Oribatid mites show that soil food web complexity and close aboveground-belowground linkages emerged in the early Paleozoic. Communications Biology, $2(1), 387$.

Schaefer, I., Norton, R. A., Scheu, S., \& Maraun, M. (2010). Arthropod colonization of land - Linking molecules and fossils in oribatid mites (Acari, Oribatida). Molecular Phylogenetics and Evolution, 57(1), 113-121.

Schröder, B. (2008) Challenges of species distribution modeling belowground. Journal of Plant Nutrition and Soil Science, 171, 325-337.

Shade, A., Dunn, R. R., Blowes, S. A., Keil, P., Bohannan, B. J. M., Herrmann, M., ... Chase, J. (2018). Macroecology to Unite All Life, Large and Small. Trends in Ecology \& Evolution, $33(10), 731-744$. 
Shoemaker, W. R., Locey, K. J., \& Lennon, J. T. (2017). A macroecological theory of microbial biodiversity. Nature Ecology \& Evolution, 1(5), 0107.

Shokralla, S., Gibson, J. F., King, I., Baird, D. J., Janzen, D. H., Hallwachs, W., \& Hajibabaei, M. (2016). Environmental DNA barcode sequence capture: targeted, PCR-free sequence capture for biodiversity analysis from bulk environmental samples. BioRxiv, (087437 [Preprint]), 28.

Siciliano, S. D., Palmer, A. S., Winsley, T., Lamb, E., Bissett, A., Brown, M. V., ... Snape, I. (2014). Soil fertility is associated with fungal and bacterial richness, whereas $\mathrm{pH}$ is associated with community composition in polar soil microbial communities. Soil Biology and Biochemistry, 78, $10-20$.

Smith, A. B., Sandel, B., Kraft, N. J. B., \& Carey, S. (2013). Characterizing scale-dependent community assembly using the functional-diversity-area-relationship. Ecology, 94(11), 23922402.

Soininen, J. (2012). Macroecology of unicellular organisms - patterns and processes. Environmental Microbiology Reports, 4(1), 10-22.

Soininen, J., McDonald, R., \& Hillebrand, H. (2007). The distance decay of similarity in ecological communities. Ecography, 30(1), 3-12.

Solomou, A. D., Sfougaris, A. I., Vavoulidou, E. M., \& Csuzdi, C. (2013). Species richness and density of earthworms in relation to soil factors in olive orchard production systems in Central Greece. Communications in Soil Science and Plant Analysis, 44(1-4), 301-311.

Sosa-Hernández, M. A., Roy, J., Hempel, S., \& Rillig, M. C. (2018). Evidence for subsoil specialization in arbuscular mycorrhizal fungi. Frontiers in Ecology and Evolution, 6, 1-7.

Soudzilovskaia, N. A., Vaessen, S., Barcelo, M., He, J., Rahimlou, S., Abarenkov, K., ... Tedersoo, L. (in press). FungalRoot: Global online database of plant mycorrhizal associations. New Phytologist. 
Staniczenko, P. P. A., Sivasubramaniam, P., Suttle, K. B., \& Pearson, R. G. (2017). Linking macroecology and community ecology: refining predictions of species distributions using biotic interaction networks. Ecology Letters, 20(6), 693-707.

Stehli, F. G., Douglas, R. G., \& Newell, N. D. (1969). Generation and Maintenance of Gradients in Taxonomic Diversity. Science, 164(3882), 947-949.

Swenson, N. G., \& Jones, F. A. (2017). Community transcriptomics, genomics and the problem of species co-occurrence. Journal of Ecology, 105(3), 563-568.

Tedersoo, L., Anslan, S., Bahram, M., Põlme, S., Riit, T., Liiv, I., ... Abarenkov, K. (2015). Shotgun metagenomes and multiple primer pair-barcode combinations of amplicons reveal biases in metabarcoding analyses of fungi. MycoKeys, 10, 1-43.

Tedersoo, L., Bahram, M., Polme, S., Koljalg, U., Yorou, N. S., Wijesundera, R., ... Abarenkov, K. (2014). Global diversity and geography of soil fungi. Science, 346(6213), 1256688-1256688.

Thakur, M. P., Phillips, H. R. P., Brose, U., De Vries, F. T., Lavelle, P., Loreau, M., ... Cameron, E. K. (2019). Towards an integrative understanding of soil biodiversity. Biological Reviews, 95(2), 350-364.

Thompson, L. R., Sanders, J. G., McDonald, D., Amir, A., Ladau, J., Locey, K. J., ... Zhao, H. (2017). A communal catalogue reveals Earth's multiscale microbial diversity. Nature, 551, $457-$ 463.

Tremblay, J., Singh, K., Fern, A., Kirton, E. S., He, S., Woyke, T., ... Tringe, S. G. (2015). Primer and platform effects on 16S rRNA tag sequencing. Frontiers in Microbiology, 6, 1-15.

Tukiainen, H., Alahuhta, J., Field, R., Ala-Hulkko, T., Lampinen, R., \& Hjort, J. (2017). Spatial relationship between biodiversity and geodiversity across a gradient of land-use intensity in high-latitude landscapes. Landscape Ecology, 32(5), 1049-1063. 
Vályi, K., Mardhiah, U., Rillig, M. C., \& Hempel, S. (2016). Community assembly and coexistence in communities of arbuscular mycorrhizal fungi. ISME Journal, 10(10), 2341-2351.

Violle, C., Reich, P. B., Pacala, S. W., Enquist, B. J., \& Kattge, J. (2014). The emergence and promise of functional biogeography. Proceedings of the National Academy of Sciences, 111(38), 1369013696.

Wagg, C., Bender, S. F., Widmer, F., \& van der Heijden, M. G. A. (2014). Soil biodiversity and soil community composition determine ecosystem multifunctionality. Proceedings of the National Academy of Sciences, 111(14), 5266-5270.

Ward, S. E., Smart, S. M., Quirk, H., Tallowin, J. R. B., Mortimer, S. R., Shiel, R. S., Wilby, A., \& Bardgett, R. D. (2016). Legacy effects of grassland management on soil carbon to depth. Global Change Biology, 22(8), 2929-2938.

Wardle, D. A., Bardgett, R. D., Klironomos, J. N., Setala, H., van der Putten, W. H., \& Wall, D. H. (2004). Ecological Linkages Between Aboveground and Belowground Biota. Science, 304(5677), 1629-1633.

Warton, D. I., Blanchet, F. G., O’Hara, R. B., Ovaskainen, O., Taskinen, S., Walker, S. C., \& Hui, F. K. C. (2015). So Many Variables: Joint Modeling in Community Ecology. Trends in Ecology and Evolution, 30(12), 766-779.

White, E., Adler, P., \& Lauenroth, W. (2006). A comparison of the species-time relationship across ecosystems and taxonomic groups. Oikos, 112(1), 185-195.

White, H. J., Montgomery, W. I., Storchová, L., Hořák, D., \& Lennon, J. J. (2018a). Does functional homogenization accompany taxonomic homogenization of British birds and how do biotic factors and climate affect these processes? Ecology and Evolution, 8(15), 7365-7377. 
1024

1025

1026

1027

1028

1029

1030

1031

1032

1033

1034

1035

1036

1037

1038

1039

1040

1041

1042

1043

1044

1045

White, H. J., Montgomery, W. I., Pakeman, R. J., \& Lennon, J. J. (2018b). Spatiotemporal scaling of plant species richness and functional diversity in a temperate semi-natural grassland. Ecography, $41(5), 845-856$.

Wong, M. K. L., \& Guénard, B. (2017). Subterranean ants: Summary and perspectives on field sampling methods, with notes on diversity and ecology (Hymenoptera: Formicidae). Myrmecological News, 25, 1-16.

Wu, J. (2004). Effects of changing scale on landscape pattern analysis: Scaling relations. Landscape Ecology, 19(2), 125-138.

Zanne, A. E., Abarenkov, K., Afkhami, M. E., Aguilar-Trigueros, C. A., Bates, S., Bhatnagar, J. M., ... Treseder, K. K. (2020). Fungal functional ecology: bringing a trait-based approach to plantassociated fungi. Biological Reviews, 95(2), 409-433.

Zanne, A. E., Powell, J. R., Flores-Moreno, H., Kiers, E. T., van 't Padje, A., \& Cornwell, W. K. (in press). Finding fungal ecological strategies: Is recycling an option? Fungal Ecology.

Zhang, W., Hendrix, P. F., Snyder, B. A., Molina, M., Li, J., Rao, X., ... Fu, S. (2010). Dietary flexibility aids Asian earthworm invasion in North American forests. Ecology, 91(7), 20702079. 
Table 1 Examples of existing databases that include soil biodiversity or distribution data.

\begin{tabular}{|c|c|c|c|c|c|}
\hline Database Website & Database Name & Taxa & $\begin{array}{l}\text { Geographic } \\
\text { coverage }\end{array}$ & $\begin{array}{l}\text { Taxonomic } \\
\text { resolution }\end{array}$ & $\begin{array}{l}\text { Year } \\
\text { compiled }\end{array}$ \\
\hline $\begin{array}{l}\begin{array}{l}\text { https://data.bioplatf } \\
\text { orms.com/organiza } \\
\text { tion/about/bpa-base }\end{array} \\
\end{array}$ & \begin{tabular}{|l} 
Biome of \\
Australian Soil \\
Environments \\
\end{tabular} & Microbes & $\begin{array}{l}\text { Australia and } \\
\text { Antarctica }\end{array}$ & $\begin{array}{l}\text { Molecular } \\
\text { (OTU) }\end{array}$ & 2016 \\
\hline http://drilobase.org/ & $\begin{array}{l}\text { Drilobase - the } \\
\text { World Earthworm } \\
\text { Database }\end{array}$ & Earthworms & Global & Species & $\begin{array}{l}2014- \\
\text { present }\end{array}$ \\
\hline $\begin{array}{l}\text { http://www.earthmi } \\
\text { crobiome.org/ }\end{array}$ & $\begin{array}{l}\text { Earth Microbiome } \\
\text { Project }\end{array}$ & Microbes & Global & $\begin{array}{l}\text { Molecular } \\
(\text { OTU) }\end{array}$ & 2017 \\
\hline $\begin{array}{l}\text { https://edaphobase. } \\
\text { org/ }\end{array}$ & Edaphobase & Soil fauna & $\begin{array}{l}\text { Germany } \\
\text { (predominantly) }\end{array}$ & Species & $\begin{array}{l}2014- \\
\text { present }\end{array}$ \\
\hline $\begin{array}{l}\text { http://maarjam.bota } \\
\text { ny.ut.ee/ }\end{array}$ & MaarjAM & $\begin{array}{l}\text { Arbuscular } \\
\text { mycorrhizal } \\
\text { fungi }\end{array}$ & Global & $\begin{array}{l}\text { Molecular } \\
\text { (small sub-unit } \\
\text { rRNA } \\
\text { sequences) }\end{array}$ & 2010 \\
\hline $\begin{array}{l}\text { https://catalogue.ce } \\
\text { h.ac.uk/documents/ } \\
\text { 53210c27-87fc- } \\
\text { e6e4-a3d6- } \\
\text { e731003dc541 } \\
\end{array}$ & $\begin{array}{l}\text { Model estimates of } \\
\text { topsoil microbes } \\
\text { [Countryside } \\
\text { Survey] } \\
\end{array}$ & Bacteria & Great Britain & $\begin{array}{l}\text { Molecular } \\
\text { (terminal } \\
\text { restriction } \\
\text { fragments) }\end{array}$ & 2007 \\
\hline https://nbnatlas.org & $\begin{array}{l}\text { National } \\
\text { Biodiversity } \\
\text { Network Atlas }\end{array}$ & $\begin{array}{l}\text { Various, } \\
\text { including } \\
\text { soil biota }\end{array}$ & $\begin{array}{l}\text { Great Britain } \\
\text { and Northern } \\
\text { Ireland }\end{array}$ & Variable & $\begin{array}{l}2000- \\
\text { present }\end{array}$ \\
\hline $\begin{array}{l}\text { http://data.nhm.ac. } \\
\text { uk/dataset/the- } \\
\text { 2016-release-of- } \\
\text { the-predicts- } \\
\text { database }\end{array}$ & PREDICTS & $\begin{array}{l}\text { Various, } \\
\text { including } \\
\text { soil biota }\end{array}$ & Global & $\begin{array}{l}\text { Predominantly } \\
\text { species }\end{array}$ & 2016 \\
\hline $\begin{array}{l}\text { https://catalogue.ce } \\
\text { h.ac.uk/documents/ } \\
\text { fccd86b0-f5b6- } \\
\text { 4716-b4f7- } \\
\text { f43ad82daeee } \\
\end{array}$ & $\begin{array}{l}\text { Soil Invertebrates } \\
\text { Countryside Survey }\end{array}$ & $\begin{array}{l}\text { Soil } \\
\text { invertebrates }\end{array}$ & Great Britain & Class/Order & 2007 \\
\hline
\end{tabular}


1053 Figure 1. Considering different soil habitats and corresponding sampling methods adds

1054 dimensionality to macroecological approaches.

1055

1056 Figure 2. The challenges associated with the belowground system which contributed to a lack of soil

1057 macroecological research, and potential approaches to address them. These challenges can be

1058 separated into four sets of necessary considerations: data; spatio-temporal; biotic; and abiotic.

1059 Challenges for each solution are highlighted in central darker boxes whilst example approaches to

1060 address these challenges are shown in the surrounding, lighter boxes. J-SDMs $=$ joint species

1061 distribution modeles; $\mathrm{AMF}=$ arbuscular mycorrhizal fungi; $\mathrm{PCNM}=$ Principal Coordinates of

1062 Neighbourhood Matrices.

1063 